\title{
The Circular Economy: An Opportunity for Renewal, Growth, and Stability
}

\author{
Mark Esposito, Terence Tse and Khaled Soufani
}

\section{Introduction}

Since the industrial revolution, we have been living in a linear economy. Our producers and "single use" lifestyles have made the planet a "take, make, dispose" world. For those unfamiliar with the phrase, it refers to a very one-directional model of production: natural resources provide our factory inputs, which are used to create mass-produced goods to be purchased and typically thrown away after a single use. Thrown away though, does not capture in any capacity the reality of what actually happens; what remains after use is christened as trash and go on to spend the rest of eternity in a landfill instead of having parts reclaimed or remanufactured for other uses. It becomes obvious very quickly that the mode of a linear economy is unsustainable. Our model of mass production and mass consumption is testing the physical limits of the globe and threatening the stability of our future.

Fundamental resources such as water, food, and energy are at stake. The energy that we expend today to operate cars, airplanes, overhead lights, and other modern-day technologies, took billions of years for the planet to collect and to store in plants and fossil fuels. Now we spend that energy at a much faster rate than the planet can produce.

Resource scarcity is a real problem. The nonprofit group Forum for the Future estimates that we are consuming resources $50 \%$ faster than can be replaced. By 2030 , our demand will require more than two planets worth of natural resources if they are to be met. ${ }^{1}$ By 2050, three planets' worth. ${ }^{2}$ Moreover, according to the OECD, the global middle class will have doubled by the year 2030, which will drive demand for resource-intensive goods such as vehicles and other contemporary conveniences that many of us in advanced industrialized countries enjoy today. ${ }^{3}$

It gets worse. It isn't just that we are using resources faster than the Earth can possibly produce; our global economic productivity is also falling, despite technology and efficiency improvements invented over the decades. Because our natural capital is rapidly depleting and affecting our world ecology even as we continue to invent and innovate, our output is no longer as great as it used to be, in an ironic backslide in productivity across time. For instance, in spite of technological advances in fertilization and irrigation, productivity gains in grain crops have fallen $66 \%$ since the $1970 \mathrm{~s}^{4}$ In another example, constant mining of the earth has also taken its toll. The average percentage of metals retrieved from mining has slowly been falling in terms of both quality and concentration, making mining a more expensive proposition. ${ }^{5}$ Productivity is also

\footnotetext{
${ }^{1}$ Forum for the Future and Retail Industry Leaders Association, "Retail Horizons - Toolkit," 56, accessed August 9, 2015, http://www.forumforthefuture.org/sites/default/files/Retail\%20Horizons\%20-\%20Toolkit.pdf

${ }_{2}^{2}$ Peter Lacy, "The Circular Economy. Great Idea, But Can It Work?" Forbes, accessed August 2, 2015, http://www.forbes.com/sites/valleyvoices/2015/01/20/the-circular-economy-great-idea-but-can-it-work/.

${ }^{3}$ OECD, "Perspectives on Global Development 2012: Social Cohesion in a Shifting World," OECD Publishing, 2011, 18.

${ }^{4}$ Ibid, 23.

${ }^{5}$ Ibid, $22-23$.
} 
beholden to the planet: when a drought kills entire crops in a region or a widespread disease kills tens of thousands of livestock, those foods become more expensive for everyone, or in some cases, not available at all.

But despite these sobering statistics, all is not lost. Thanks to organizations like the World Economic Forum and the Ellen MacArthur Foundation, research on a different model of consumption and production, called the circular economy, is gaining more attention recently.

\section{The Circular Economy}

While many current sustainability paradigms revolve around doing more with less, the circular economy is also recuperative. In terms of sustainability, it would be incomplete to say that the circular economy is environmentally friendly. While that may be one of its characteristics, the circular economy is not just about feel-good, idealistic words like recycling. The circular economy is focused on maximizing what is already in use along all points of a product's lifecycle, from sourcing, to supply chain, to consumption, to the remaining unusable parts for one function and converted back into a new source for another purpose. Researchers and modeling experts at the Ellen MacArthur Foundation and the McKinsey Center for Business and Environment estimate that, in a circular economy scenario, consumption of new materials could be reduced by as much as 32 percent within fifteen years, and by 2050 , by more than half at $53 \% .{ }^{6}$ Instead, primary materials used in construction, car manufacturing, synthetic fertilizers and pesticides, fuel and non-renewable energy, and land use among other uses, can be replaced with recovered and repurposed materials in cascaded use.

Examples of low utilization are abound in advanced industrialized countries. In Europe. for instance, researchers discovered in a study that cars were parked $92 \%$ of the time. ${ }^{7}$ In the workplace, offices are used only $35-40 \%$ - and that's during working hours. ${ }^{8}$ Moreover, the opportunity for new efficiencies is greater than ever, and across all industries and aspects of the supply chain - for instance, according to the Ellen MacArthur Foundation, only $40 \%$ of irrigation water actually reaches plants. ${ }^{9}$ For the US, opportunities to benefit from the circular economy are particularly good. With its position as a consumption-based economy among other smaller countries that must most of its import raw materials, the US can be a seller of materials for other nations while insulating itself from price volatility and waste. Not only that, but moving toward a circular economy could eliminate 100 million tons of materials waste globally in the next five years alone. ${ }^{10}$

${ }^{6}$ Ellen MacArthur Foundation and the McKinsey Center for Business and Environment, "Growth Within: A Circular Economy Vision for a Competitive Europe," Foundation for Environmental Economics and Sustainability (SUN [Stiftungsfonds für Umweltökonomie] and Nachhaltigkeit GmbH), June 2015, 15.

${ }^{7}$ Ellen MacArthur Foundation, "Growth Within," 18.

${ }^{8}$ Ibid., 20.

${ }^{9}$ Ellen MacArthur Foundation, "Growth Within," 20. These are independent calculations made by the publication's researchers based on data from the European Environment Agency. See: European Environment Agency, "Towards Efficient Use of Water Resources in Europe," 2012.

${ }^{10}$ World Economic Forum, "Towards the Circular Economy: Accelerating the scale-up across global supply chains," Report, January 2014, 11, accessed August 2, 2015, http://www3.weforum.org/docs/WEF_ENV_TowardsCircularEconomy_Report_2014.pdf. 


\section{How Do We Start?}

Although the logistics of implementation on a visionary scale still have many unanswered questions, some initial areas of opportunity point to the first steps toward creating a circular economy.

\section{The Virtue of Proximity: Materials Recovery and Economies of Scale}

Central sites of human activity are an opportunity to capture economies of scale. Today, over half the human population lives in urban environments. Future projections indicate the number will be even greater by 2045 when cities in developing countries catch up to the urban resident rate of advanced industrialized countries. ${ }^{11}$ Despite the fact that urban centers are heat islands and hubs of pollution, "megacities" are here to stay. Fortunately, the concentration of human activity in cities means that it is that much more realistic for us to recover and treat postconsumer materials on a large scale to prepare them for re-use in a new capacity.

As a model of circular economy theory in action, the transnational company Veolia is already hard at work to create a closed loop with urban waste. Veolia operates in 40 countries, working with both industry customers and municipalities to collect, sort, and treat waste from industrial environments and households, and to operate landfills and treat wastewater. ${ }^{12}$ After processing, municipal and industrial waste is reintroduced into production systems for reuse. Treated wastewater becomes potable water and is also used in other regenerative processes such as the making of agricultural fertilizer and for power generation.

\section{The Shared Economy and Urban Environments: Matching Demand with Capacity}

Another opportunity for the circular economy through the urban environment is the ability to align demand with the capacity of the shared economy. The Internet and software technology has eliminated the high cost of and logistical barriers to on-demand communication and making peer-to-peer transactions, opening up a pathway for sharing and renting resources from either private owners or within public systems, such as citywide bike-sharing programs as seen in cities including Boston and Washington, DC. With so much private and individual excess capacity available and concentrated in urban areas, the sharing economy is poised to make an impact on resource use. Currently, car-sharing is one of the most well known concepts of the sharing economy. Car-sharing is available in a number of ways-users can either rent cars from car owners rather than buy a car of their own; hire a car and its owner to do the driving; or connect with drivers headed in the same direction with a few extra seats to spare to split the cost of gasoline. With these three car-sharing models working in tandem within megacities, carsharing keeps fewer cars on the road, meaning less pollution in the air, fewer primary materials used, and less transportation capacity wasted.

Other areas of the shared economy, such as short-term home sharing, makes it possible to avoid building more hotels to meet demand. Airbnb, which brokers such transactions and

${ }^{11}$ United Nations Department of Economic and Social Affairs, "World's population increasingly urban with more than half living in urban areas," United Nations, July 10, 2014, accessed July 29, 2015 , http://www.un.org/en/development/desa/news/population/world-urbanization-prospects-2014.html.

${ }^{12}$ Veolia. "Reinventing Veolia's Businesses.” Report, 6. January 24, 2013. Accessed July 29, 2015. http://www.finance.veolia.com/docs/Veolia_Press_Day_English.pdf 
founded only seven years ago in 2008, now operates in over 34,000 cities and 137 countries with over 20 million registered members. ${ }^{13}$ The growing success of companies in the sharing economy such as Airbnb and Uber, which operates in fifty-two countries and still expanding further, illustrate the economy of scale and the viability of sharing access to products and services-an important principle of the circular economy. ${ }^{14}$

\section{The Built Environment: Improved Technology and Better Urban Planning}

A third area of immediate opportunity is within the built environment. Aside from virtualizing the office and/or sharing physical office space, new technologies and methods-including 3D printing, solar and green roofing; smart energy management and monitoring; use of renewable materials; and better design-have the potential to improve how we use space and how we store and use energy. More importantly, there is also ample room for improvement in how we manage our construction waste to move the circular economy forward. Presently, only $85-90 \%$ of building materials are actually used during construction, and when an older building is torn down, over half of the demolition materials get sent to the landfill, when those materials could in fact be reused again. ${ }^{15}$

Other ways to capture waste and lost opportunity include the land itself: dense, optimized cities can be achieved by reclaiming vacant land in the inner-city and allowing for mixed-use buildings instead of permitting an endless urban sprawl.

\section{New Regulatory Frameworks: Leadership for a Circular Economy}

Lawmakers have many different levers available to them to encourage circular economy principles. As an example of how governments in the U.S. can spur change toward a circular economy, already thirty-one states have variously passed what are known as product stewardship (producer responsibility) laws, in which companies must take responsibility for the environmental, health, and safety ramifications of their products. ${ }^{16}$ Some states have also completely banned organic matter from landfills, which has motivated businesses to focus on reducing the amount of food waste generated. ${ }^{17}$ In addition to providing responsibility laws and directives, policymakers can also leverage tax laws and other business incentives. Today, taxes are mostly focused on income and labor. Rather than taxing labor, taxing businesses and companies that consume more resources instead will create a dual benefit of motivating companies to reduce consumption and slow down the depletion of natural capital, while also placing more value on labor, creating an opportunity for policymakers to encourage job creation in addition to circular economy principles.

Additionally, regulations that favor traditional, linear economy businesses or that have been barriers to circular economy principles such as the sharing economy, will need to be revisited if we are to address the long-term challenge of resource dependency. Legislators must be able to

${ }^{13}$ Ellen MacArthur Foundation, "Growth Within," 25.

${ }^{14}$ Ensor, Josie, "Uber: where does the online taxi service operate - and where has it been banned?", The Guardian, accessed July 10, 2015, http:/www.telegraph.co.uk/news/worldnews/11288103/Uber-where-does-theonline-taxi-service-operate-and-where-has-it-been-banned.html.

${ }^{15}$ Ellen MacArthur Foundation, "Growth Within," 82.

${ }^{16}$ Forum for the Future, "Retail Horizons," 53.

17 Ibid. 
find a balance between addressing regulatory concerns while also paving the way for the sharing economy to play a meaningful role in the circular economy. All told, policymakers have immense power and influence when it comes to regulating and supporting important systems and functions of the circular economy.

\section{Measuring Progress}

Of course, questions of metrics and progress must be asked: how exactly do we measure the gains from a circular economy? Some tools have already been developed that we can use today. The System of Environmental-Economic Accounting allows us to calculate degradationadjusted net value add (NVA). ${ }^{18}$ Meanwhile, the European Commission's Eurostat has created a Resource Efficiency Scoreboard to calculate GDP generated per unit of net virgin finite material input. ${ }^{19}$ Moreover, the total cost of externalities and opportunity cost of not changing can also be gathered using preexisting methods of measuring human activity's impact on issues such as water pollution and toxicity, air quality, congestion, and public health. ${ }^{20}$

\section{Shared Planet, Shared Fate}

The current steps described herein are just the first steps for moving toward a circular economy. There is much more work to be done in terms of getting companies to collaborate together to reduce waste and also to share and trade reusable inputs, instead of just competing for customers and revenue. Different groups, including municipal and top-level governments, firms, and local businesses, will have to cooperate to steward our valuable resources for the best outcomes. Though competition for resources, political instability, and greater variance in food security and global climate may threaten our way of life, there are opportunities ahead for us to find ways to preserve our natural capital while also extending the quality of life on our planet. The circular economy provides some guidance to what it will take to permanently reduce our dependency on the limited natural resources that may not always be there when we need it. The circular economy will undoubtedly come to pass, if not out of choice, out of necessity.

As the circular economy's objective is to decouple growth and production from a dependence on natural resources, the circular economy model require us to implement new paradigms into today's systems on a collaborative scale to make a real impact. The industrial revolution and our resulting linear economy may have forever changed the earth's ecology and our relationship with the environment, but what is changed can continue to change, this time for the better.

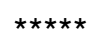

\footnotetext{
${ }^{18}$ Environment Agency, "Towards Efficient Use," 48.

${ }^{19}$ Ellen MacArthur Foundation, "Growth Within," 25.

${ }^{20}$ Ibid.
} 


\section{Bibliography}

Brookings Institute. "Global Metro Monitor.” Accessed August 1, 2015.

http://www.brookings.edu/research/reports2/2015/01/22-global-metro-monitor.

Council for the Environment and Infrastructure. "Circular Economy: From Wish to Practice." June 2015. Accessed August 1, 2015.

http://en.rli.nl/sites/default/files/150615_rli_advice_circular_economy_from_wish_to_practice_1. pdf.

Ellen MacArthur Foundation and the McKinsey Center for Business and Environment. "Growth Within: A Circular Economy Vision for a Competitive Europe." Foundation for Environmental Economics and Sustainability. June 2015.

Ensor, Josie, "Uber: where does the online taxi service operate - and where has it been banned?", The Guardian. Accessed July 10, 2015.

http://www.telegraph.co.uk/news/worldnews/11288103/Uber-where-does-the-online-taxiservice-operate-and-where-has-it-been-banned.html.

European Commission. "Nearly-Zero Energy Buildings." Last modified August 18, 2015. https://ec.europa.eu/energy/en/topics/energy-efficiency/buildings/nearly-zero-energy-buildings.

Eurostat. "Unemployment Statistics - Statistics Explained." Eurostat. Accessed July 20, 2015. http://ec.europa.eu/eurostat/statistics-explained/index.php/Unemployment_statistics.

Fischer-Kowalski, M. et al. "Decoupling Natural Resource Use and Environmental Impacts from Economic Growth. Report of the Working Group on Decoupling to the International Resource Panel." United Nations Environment Program. 2011.

Forum for the Future and Retail Industry Leaders Association, "Retail Horizons - Toolkit," Accessed August 9, 2015.

http://www.forumforthefuture.org/sites/default/files/Retail\%20Horizons\%20-\%20Toolkit.pdf.

Global Commission on the Economy and Climate. "Better Growth Better Climate: The New Climate Economy Report - The Synthesis Report." Report. September 2014. Accessed August 1, 2015. http://newclimateeconomy.report/TheNewClimateEconomyReport.pdf.

Hajer, Maaarten. "Europe needs 'smart urbanism' not 'smart cities'." The Parliament Magazine. May 28, 2014. Accessed July 28, 2015.

https://www.theparliamentmagazine.eu/articles/feature/europe-needs-smart-urbanism-notsmart-cities.

Lacy, Peter. "The Circular Economy. Great Idea, But Can It Work?" Forbes. Accessed August 2, 2015, http://www.forbes.com/sites/valleyvoices/2015/01/20/the-circular-economy-great-idea-butcan-it-work/.

Mohindra, Desiree. "Circular Economy Can Generate US\$1 Trillion Annually by 2025." World Economic Forum. Press release. Accessed August 1, 2015.

http://www.weforum.org/news/circular-economy-can-generate-us-1-trillion-annually-2025.

OECD. "Perspectives on Global Development 2012: Social Cohesion in a Shifting World." OECD Publishing. 2011. 
Tellus Institute, "More Jobs, Less Pollution - Growing the Recycle Economy in the US, 2013. Accessed July 21, 2015. http://www.tellus.org/pub/More\%20Jobs,\%20Less\%20Pollution\%20\%20Growing\%20the\%20Recycling\%20Economy\%20in\%20the\%20US.pdf.

Ton Bastein, et al. "Opportunities for a Circular Economy in the Netherlands." Netherlands Organization for Applied Scientific Research. 2013.

United Nations Department of Economic and Social Affairs. "World's population increasingly urban with more than half living in urban areas." United Nations. July 10, 2014. Accessed August 2, 2015. http://www.un.org/en/development/desa/news/population/world-urbanizationprospects-2014.html.

Veolia. “2013 Key Figures.” Report. Accessed July 29, 2015.

http://www.veolia.com/sites/g/files/dvc181/f/assets/documents/2014/06/veolia_keyfigures_gb.pdf.

Veolia. "Reinventing Veolia's Businesses." Report, 6. January 24, 2013. Accessed July 29, 2015. http://www.finance.veolia.com/docs/Veolia_Press_Day_English.pdf.

World Economic Forum. "Towards the Circular Economy: Accelerating the scale-up across global supply chains.” Report. January 2014. Accessed August 2, 2015.

http://www3.weforum.org/docs/WEF_ENV_TowardsCircularEconomy_Report_2014.pdf. 